\title{
Word volgelinge van sommige hedendaagse "profete" mislei en van hulle regte ontneem onder die dekmantel van profesie?
}

S P Pretorius

(Universiteit van Suid Afrika)

\section{ABSTRACT \\ Are followers of certain modern day 'prophets' been mislead and deprived of their rights under the pretences of prophecy?}

Prophets and their prophecies seem to form an integral part of the spirituality of some believers. A small group of believers in Hertzogville are clinging wholeheartedly to the prediction uttered by their 'prophet', a certain David Francis. According to Francis, God gave him a message on 1 July 2004 that the deceased, Paul Meintjies, should not be buried because he would rise from the dead. Francis gave no specific date for the resurrection - God will speak to him when the time is right. Although Francis could give no specific date, rumours amongst the people in Hertzogville had it that the resurrection would take place on 29 July 2004. This date was later changed to 5 and then to 8 August 2004. Nothing happened on any of these dates. In spite of everything, the followers of Francis still believe that Meintjies will rise from the dead.

In this article the claim of modern day 'prophet' and their socalled godly messages are evaluated. This is done in light of the Biblical prophets. Judging by the actions of his followers, it seems that Francis has gained some sort of control over them, affecting their whole lives. The prophecy appears to be instrumental in the control he has over his followers. How this 'control' over his followers affect their whole lives and in particular their rights is also investigated

The conclusion is that modern 'prophets' of the like of Francis gain an unethical control over their followers' lives through socalled 'prophecy'. Prophecy interpreted by his followers as 'God's Word' acts as a powerful instrument in achieving this control. In the process the followers are also denied certain rights according to the country's Constitution under the banner of freedom of religion. 


\section{INLEIDING}

Die Grondwet van die Republiek van Suid-Afrika wet 108 van 1996 [in art 15(1)] verleen aan elke burger in die land die reg om die godsdiens van sy/haar keuse te beoefen. Hierdie vryheid wat deur die Grondwet verskans word, het sekere gevolge vir spiritualiteit in die algemeen. Twee belangrike gevolge is dat godsdiens meer spontaan beoefen kan word en dat godsdiensvryheid ruimte skep vir die ontwikkeling van 'n eiesoortige spiritualiteit in elke godsdiens. Dit wil sê elke mens kan sy/haar godsdiens beoefen, watter rituele en praktyke dit ook al insluit, met dien verstande dat die regte van die persoon nie in die proses misken en die wette van die land nie deur hierdie beoefening oortree word nie.

In die lig van die voorgaande moet die gebeure met betrekking tot die profesie deur die profeet op Hertzogville dan ook as deel van die spiritualiteit van 'n klein groepie bekend as Aksie vir Christus Ministerie Koninkryk van God op Aarde beskou word. Die optrede van hedendaagse profete, insluitende die profeet op Hertzogville, en die reaksie van hul volgelinge laat egter ernstige vrae ontstaan oor hoe vry die beoefening van ' $\mathrm{n}$ spesifieke godsdiens werklik is.

\section{PROBLEEMSTELLING}

Die vraag is of hedendaagse profete soos die profeet te Hertzogville, nie by wyse van sogenaamde profesieë wat hulle van "God" ontvang het, hul volgelinge se totale lewe beheer onder die dekmantel van godsdiensvryheid nie. Verder: Is die gevolg van hierdie beheer nie ook die miskenning van sekere regte van hierdie volgelinge nie?

\section{BYBELSE PROFETE}

'n Bondige oorsig van die Bybelse profeet dien as agtergrond waarteen die aansprake en optrede van die hedendaagse profete beoordeel kan word.

Daar is bykans geen volk op aarde wat nie bekend is met die een of ander openbaring wat van hulle god afkomstig is nie. Oral in die wêreld, in bykans elke eeu, het geïnspireerde mense na vore getree wat geglo het dat hulle toegerus is met ' $n$ geestelike gawe wat aan hulle toegang verleen tot okkulte bronne van kennis. Daar is 'n lang geskiedenis van profetiese aktiwiteit in die Antieke NabyeOoste. 'n Groot deel van hierdie aktiwiteit is geassosieer met die praktyk van waarsêery en die interpretasie van voortekens. Die taak van ' $n$ waarsêer is om die wil van 'n god of gode te bepaal deur 
verskeie rituele aksies, byvoorbeeld om die ingewande van 'n skaap te besigtig, die dooies te konsulteer (1 Sam 28:8) of astrologiese verskynsels te bestudeer (Matthews 2001:19).

Die vraag wat in hierdie verband belangrik is, is nie of daar in ander godsdienste aanspraak op goddelike openbaring of op "profete" gemaak word nie, maar eerder of mense met 'n profetiese gawe nog te vinde is buite die konteks van die Bybelse Israel.

Drie woorde vir "profeet" word in die Ou Testament aangetref. Die mees algemene woord is navi. Hierdie woord word wyd aangetref en verwys na 'n breë verskeidenheid van mense van Genesis (met betrekking tot Abraham - Gen 20:7) tot en met die boek Maleagi (met betrekking tot Elia - Mal 4:5). Daar word egter ook twee ander woorde hiervoor gebruik, naamlik die woorde ro'eh en hozeh. Albei hierdie woorde word vertaal as "siener": 'een wat in die toekoms kan sien' of 'iemand wat heldersiende is' (Zucker 1994:15). 'n Onderskeid kan waarskynlik verder tussen die twee woorde gemaak word. Sandmel (1963:49) stel voor dat ro'eh vertaal kan word as "siener" en hozeh in sommige gevalle as "iemand wat staar". Die woorde vir sieners word egter minder gebruik as die woord navi. Die woord navi is spaarsaam gebruik voor die tydperk van die monargie, en meer gereeld in die tydperk van die klassieke profete (750-550 vC) (Napier 1962:905). Die gebruik van die woord vóór die tydperk van die monargie is ietwat anachronisties. Dit word baie selde voor die middel van die elfde eeu $\mathrm{vC}$ gebruik, wat moontlik daarop kan dui dat dit die werk van latere redakteurs van die Ou Testament gedeeltes is waar oor die monargie berig word en meer spesifiek die voor die monargiese tydperk. Die redakteurs wou waarskynlik daardeur aandui dat Abraham, Moses, Aäron, Mirjam en Debora as segsmense vir God opgetree het en dus die gedrag van 'n navi geopenbaar het. Freeman (1971:11) verduidelik dat die geskiedenis van Israel gegrond was op die openbaring van God eerder as op metafisiese spekulasie, bygelowe of filosofie. Dit verduidelik moontlik waarom die historiese boeke Josua, Rigters, Samuel en Konings in die Hebreeuse kanon die "vroeëre profete" genoem word. Die outeurs van dié boeke het net soos die latere profete die geskiedenis van Israel as 'n openbaring van God beskou. Die woord navi, of die gebruik daarvan as werkwoord word meer gereeld aangetref in die boek Samuel. Dit word hier aangewend as 'n term om waardigheid aan te dui, maar ook om die ekstatiese gedrag van 'n persoon te regverdig (Zucker 1994:16). Alhoewel die profete 
van Israel in sekere opsigte ooreenkomste met die waarsêers van die Nabye-Ooste getoon het, word hulle deur die Bybelse skrywers voorgehou as beoefenaars van godsdiens. Hulle het soms voortekens geïnterpreteer, maar was nie waarsêers nie. Hulle boodskap omtrent God se bedoeling en gedrag was nooit totaal afhanklik van die ontleding van fisiese leidrade nie. Hulle rol was om die instellings en sosiale orde van die tyd te konfronteer, om die leiers en die bevolking te herinner aan hulle verbond met Jahwe en hulle te waarsku teen die oordeel van God wat in werking sal tree as hulle die verbond verbreek (Matthews 2001:21).

Die Hebreeuse woord navi word nie net gebruik vir die profete van Jahwe wie se woord betroubaar en waar is nie. Dit sluit ook vals profete, professionele profete, hofprofete en selfaangestelde profete in (McKenna 2001:24). Die profeet Jeremia (Jer 14:14) het die volgende te sê oor dié profete: "Ek het nie hierdie profete gestuur nie; tog het hulle met ' $\mathrm{n}$ boodskap rondgehardloop; Ek het nie met hulle gepraat nie, tog het hulle as profete opgetree.

Die profeet is beskou as 'n segspersoon van God. Sandmel (1963:48) beskryf 'n profeet as volg: "someone deemed close to Deity, a person who through some form of special knowledge or revelation was able to predict what would be".

\subsection{Karaktertrekke van die Bybelse profeet in die $\mathrm{Ou}$ Testament}

Die noodsaaklikheid van profete vir die bediening het sy oorsprong by Moses, wat voorstel dat daar 'n instelling moet wees waaruit profete voortgebring kon word om die boodskap van God te verkondig (vgl Deut 18:9-22). Die doel van die profete is dat Israel deur openbaring die wil van God kan ontdek en nie soos die ander nasies gebruik hoef te maak van waarsêery en okkulte praktyke om die wil van hulle gode te ontdek nie. God sal deur die profete sy wil aan Israel openbaar (vgl Freeman 1971:25). Hierdie profete vertoon sekere eienskappe:

Goddelike roeping: Geen profeet het op eie inisiatief die roeping as profeet aanvaar nie. 'n Profeet is nie deur die koning of priester of op grond van populariteit of geboorte aangestel nie. God het mense van verskillende agtergronde geroep vir die profetiese bediening. ' $n$ Profeet wat nie deur God geroep is nie, is beskou as 'n vals profeet (Jer 14:14; 23:21). Die roeping as profeet was die gevolg van goddelike keuse. Die mens het nie die standaarde waaraan voldoen 
moet word, voorgeskryf nie (Schultz 1968:23). 'n Profeet het hom/haarself nie beskou as 'n segspersoon vir die mens nie, maar het te alle tye as 'n gestuurde van God en in die naam van God gepraat. Die doelwit van die profeet was om die verhouding tussen Israel en God te herstel (Heschel 1971:205).

Boodskap van God: Die profeet het 'n Godgegewe boodskap ontvang. Die oordrag van die boodskap aan die profeet het op 'n bonatuurlike wyse plaasgevind. Alhoewel ekstatiese ervaring soms deel gevorm het van die lewe van sommige kanoniese profete, is daar nie genoegsame bewyse wat bevestig dat profete gewoonlik in 'n toestand van ekstase hul openbaring van God ontvang het nie (Winward 1969:25). Die profeet bekom verder nie 'n openbaring deur middel van seremonies nie. Daar word nêrens verneem van uiterlike rituele wat nodig was om te profeteer nie. Momente van inspirasie kom na die profeet sonder inspanning, manipulering of voorbereiding en gebeur onverwags. Elke profeet het 'n spesifieke boodskap van God ontvang (Schultz 1968:26). Hierdie boodskap is gewoonlik aan die profeet gegee wanneer hy/sy geroep is (Bright 1959:166). Die profeet het altyd gespreek in die naam van God. Die aanhef van sy boodskap was "so sê die Here (Jahwe)" (Matthews 2001:29). Die profeet het geloofwaardigheid by die mense verkry deur die vervulling van die woord wat hy/sy gespreek het (Matthews 2001:30). Die profeet was toegerus met bonatuurlike gawes ten einde sy/haar missie uit te voer. God het deur goddelike krag sy doel met die profeet bereik (Schultz 1968:30).

Verantwoordelik aan God: Die profeet was direk verantwoordelik aan God. Die profeet se goddelike roeping om God se boodskap oor te dra met die goddelike toerusting wat met hierdie taak gepaardgaan, het gemaak dat hy/sy 'n ware verteenwoordiger van God was wat dan ook aan God verantwoording moes doen vir hierdie roeping (Schultz 1968:30).

Erkenning as profeet: Die profeet het in die een of ander vorm die erkenning van die mense geniet. Somtyds het die erkenning gekom van enkele getroue volgelinge; so nie van die gemeenskap as geheel (Schultz 1968:31).

Titel: Aan die profeet is ook 'n bepaalde titel gegee, naamlik "man van God", "vrou van God" of "dienskneg" (Schultz 1968:31). 


\subsection{Kriteria vir 'n ware profeet}

Dit blyk duidelik uit die voorgaande dat daar vals profete was. Maar waaraan is 'n ware profeet uitgeken? Afgesien daarvan dat 'n profeet deur God geroep en gestuur is, sy/haar boodskap van God ontvang het en toegerus is om die rol as profeet te vervul, is daar sekere kriteria wat ware profete van valse profete onderskei (McKenna 2001:24).

Die belangrikste kriteria kan soos volg saamgevat word. Eerstens word 'n ware profeet geken aan die vrug wat hy/sy dra. Die woord van 'n profeet moet sy/haar gehoor vul met passie en hulle motiveer om meer eerbaar op te tree, van hulself te vergeet en meer ag te slaan op ander. Profete kan binne of buite 'n spesifieke religieuse tradisie staan. Universeel het die boodskap van die profeet te doen met politiek, ekonomie en geweld, en met die slagoffers van hierdie realiteite. Die profeet se boodskap in hierdie geval is ' $n$ verklaring dat onreg geskied (McKenna 2001:25). Profete bring ook deur simboliek of gebarespel die boodskap van God. Die profeet Jeremia begrawe byvoorbeeld sy klere in die rivierbedding (Jer 13:111), leef in afsondering en weier om te trou, en begrafnisse of feesvieringe by te woon (Jer 16:1-3, vgl Matthews 2001:33). Die tweede kriterium is dat die profeet aan die kant van die slagoffers wat verontreg is, staan. Dit is die slagoffers wat weet wie die profeet is omdat die profeet hulle mondstuk is. Dit is gewoonlik hierdie identifisering met die arme, die gebrokene van hart, die gevangene, die buitestander en die sagmoedige wat woede teenoor, weerstand teen en vervolging van die profeet ontketen (McKenna 2001:25). Derdens word ' $n$ ware profeet beoordeel aan die vervulling van die profetiese woord. Die profeet spreek in die naam van Jahwe en die boodskap word bevestig deur die vervulling daarvan in die geskiedenis van die volk (Freeman 1971:106; Matthews 2001:30). Vierdens skroom 'n ware profeet ook nie om die oordeel van God te voorspel nie (Zucker 1994:31). Die profeet geniet die vryheid om selfs die konings aan te spreek oor hul sonde. Die profeet Natan spreek byvoorbeeld vir koning Dawid aan oor sy sonde teen Uria (Heschel 1971:259). Ingeweef in die tradisie van die profete is die idee dat God rou, dat Hy die swaarkry van sy mense deel en so getrou is aan hulle dat Hy naby aan hulle kom, selfs al bring hulle sonde en ongeregtigheid rampspoedige gevolge mee. Dit is hierdie God wat profete uitsoek en hulle inspireer en sy woord aan hulle gee 
sodat hulle dit aan sy mense kan oordra in die hoop dat hulle sal luister en sal terugkeer na sy weg en die vrede met Hom sal herstel.

Samevattend kan gesê word dat die profete van ouds manne en vroue was wat vervul was met God se Gees. Hierdie profete het in 'n bepaalde tyd in God se geskiedenis met sy volk in hierdie wêreld in wisselwerking getree. Hulle het gewissel van gesofistikeerde stadsbewoners, soos Jesaja en Jeremia, tot mense van die platteland, soos Amos. Hulle het as individue gespreek maar tog het hulle die woord van God gebring (Zucker 1994:196). Die spiritualiteit van die profete het op drie beginsels gestaan: profesie - die boodskap van God en die eer van die naam van God deur geregtigheid en vrede te bewerkstellig; God se getuies vir die waarheid; en medelye oorvloed in kompassie en genade (McKenna 2001:7). Hulle bestaan, verkorte lewens, opofferings, en voortydige en wrede dood roep uit vir genade en vir mense om deel te word van die stryd. Profete was magtige en invloedryke leiers in hulle tyd (Zucker 1994:2). Om 'n profeet van God te wees was nie 'n eenvoudige taak nie. Dit was 'n eensame taak en het soms gepaardgegaan met bespotting en minagting (Jurgensen 1977:20). Jeremia skryf: "Elke keer as ek my mond oopmaak, moet ek skreeu, moet ek roep: 'Daar is geweld, daar is verdrukking!' Om die woord van die Here te moet aankondig; beteken vir my net vernedering en bespotting heeldag deur." (Jer. 20:8). Die vals profeet het 'n sagte woord gespreek, terwyl die ware profeet pestilensie, verdrukking en vernietiging voorspel het. Die hedendaagse profeet kan dus in die lig van die voorgaande nie aanspraak maak op dieselfde profetiese gawe as wat in die tyd van die profete van die Bybel gegeld het nie.

\subsection{Profete en profesie in die Nuwe Testament en vroeë Christendom}

'n Aantal individue het in die literatuur van die vroeë Christene die titel "profeet" of "profetes" ontvang. In die vroeë Christendom is die eksklusiewe gebruik van die woord prophētēs as benoeming van 'n individu, medium of openbaring gelykgestel aan die Hebreeuse woord navi in Judaïsme. In die vroeë Judaïsme is die woord "profeet" selde gebruik vir persone wat nie beskou is as $\mathrm{Ou}$ Testamentiese of eskatologiese profete nie. In die Nuwe Testament word die woord prophētēs 144 keer aangetref, 86 gevalle slaan op Ou-Testamentiese profete. Insgelyks kom die woord 58 keer by die Apostoliese vaders voor, waarvan 37 slaan op die Ou-Testamentiese profete. Die vroeë Christene se benoeming van individue as 
prophètēs is hoofsaaklik bepaal deur hulle begrip van die profetiese rol in die Ou Testament (Aune 1983:195). In die vroeë Christendom is die woord prophêtēs vrylik gebruik vir die individue wat as geïnspireerde segsmense vir God beskou is. In die Evangelies word die titel tien keer gebruik vir Johannes die Doper en nege keer vir Jesus. In die Nuwe Testament word die selfstandige naamwoord prophètēs negentien keer gebruik met betrekking tot Christenindividue. Afgesien van die twaalf profete en profetesse wie se name in die boek Handelinge vermeld word, word net die name van 'Isebel' van Tiatíra (Op 2:20) en Johannes die siener (Op 22:9) in die res van die Nuwe Testament aangetref. Die ander kere wat die woord prophètēs in die Nuwe Testament aangetref word, is sonder vermelding van name (Aune 1981:198).

Die woord prophètēs in die Nuwe Testament word bykans altyd in die meervoud aangetref. Dit dui daarop dat die profete hoofsaaklik altyd in groepverband aktief was (Aune 1981:196). Op grond van bewyse in 1 Korintiërs $12-14$ wil dit voorkom asof die profete of die individue wat geprofeteer het, slegs binne die raamwerk van die Christelike aanbidding aktief was (Forbes 1995:246). In die boek Handelinge het die profete geprofeteer binne die raamwerk van 'n profetiese groep (Hand 11:27-29; 13:1-3; 15:32); by een geleentheid is Agabus egter die enigste profeet teenwoordig (Hand 21:10).

Die werkwoord prophèteuein word agt en twintig keer in die Nuwe Testament aangetref; in slegs vyf gevalle slaan dit op profetiese aktiwiteit in die Ou Testament. In die ander gevalle het dit betrekking op profesie in die vroeë Judaïsme en vroeë Christendom. Die verwysing na "profesie" in 1 Korintiërs 12:10 en Romeine 12:6 blyk nie na individuele profete te wees nie maar eerder na individue wat die gawe het om te profeteer. Die gawe van profesie in die gemeentelike konteks moet nie verwar word met die posisie of amp van "profeet" nie. Dit is waarskynlik wat Paulus bedoel met die term "profeet", naamlik dat dit iemand is wat glo dat hy/sy die gawe ontvang het om geïnspireerde uitsprake te maak. In 1 Korintiërs 12:28-29 blyk die woord "profete" te verwys na die individue wat die gawe van profeteer beoefen (Aune 1981:199). Christelike profesie word deur Forbes (1995:236) beskryf as die ontvangs van geopenbaarde waarheid en die gevolglike publieke verkondiging daarvan aan die gemeente in die naam van God/Christus en die Heilige Gees. Hy verduidelik dit soos volg: "It might include, but 
was not limited to, the prediction of the future: it might equally be unsolicited guidance, exhortation, or remonstration. It was not normally the basic gospel proclamation or kerugma itself, but might commonly be some application of its principles to a particular situation" (Forbes 1995:236).

Profesie en glossolalie in die konteks van gemeentelike aktiwiteit word genoem in die boek Handelinge (Hand 2-1-21; 8:14$17 ; 10: 44-46 ; 19: 1-6)$. In elk van die gevalle is die profesie en glossolalie die gevolg van vervulling met die Heilge Gees. In die res van die Nuwe Testament en vroeë Christelike literatuur is daar min of geen bewys dat profesie in die gemeentelike konteks aanwesig was nie.

Opsommend kan gesê word dat dit wil voorkom of die verwysing na profete in die vroeë Christendom dui op spesialiste wat die goddelike openbaring van God oorgedra het, en nie op die individue wat by geleentheid geprofeteer het nie. Laasgenoemde is 'n konsep wat oorgeneem is van die Ou-Testamentiese profete. Verder is daar ook geen bewyse dat hierdie profete, wat in groepe of afsonderlik gefunksioneer het, dit los van die Christelike aanbidding gedoen het nie. Bewyse van die gawe van profesie binne die gemeentelike konteks van die vroeë Christendom, buiten die gevalle wat in die boeke Handelinge en Korintiërs aangeteken is, is skaars. Nie net is profesie binne die gemeenskap beoefen nie, maar is dit ook gerig aan die gemeenskap en nie die buitewêreld nie. Christelike profesie was vir meer as 'n eeu in die vroeë Christelike tydperk 'n wydverspreide verskynsel. Hoewel dit gedurende hierdie tydperk verandering en ontwikkeling ondergaan het, maak die bewys van byvoorbeeld Hermas 11 dit duidelik dat profesie in die gemeentelike konteks nog aanwesig was. Die skerp afname van profesie kan moontlik toegeskryf word aan die strukture van die kerk. Terwyl sommige Pinkster- en Charismatiese kerke nog ruimte skep vir die gawe van profesie, is ander van mening dat die kanonieke boeke God se spreke geword het en dat die Woord van God die hoogste profesie is.

\section{HEDENDAAGSE PROFETE}

Hedendaagse profete speel ' $n$ belangrike rol in sommige godsdienstige groepe en mense se spiritualiteit. Te oordeel aan die aansprake en profesie van hierdie profete blyk dit dat dié "profete" hulle gelykstel aan die kanoniese profete. Die profesieë van hierdie 
profete, wat in baie gevalle ook gerig is aan die wêreld buite die groep, asook die wettiese voorskrifte van hierdie groepe, bevestig dat die profete hulle assosieer met die kanoniese profete.

Sommige mense glo dat hulle deesdae nog steeds die "woord van God" deur die "profeet" ontvang. Verskillende soorte hedendaagse "profete" kan onderskei word. Die "profete" wat egter in hierdie artikel bedoel word, is die "profete" wat in godsdienstige kultes of soortgelyke geïsoleerde groepe aangetref word.

\subsection{Godsdienstige kultes}

Daar is talle definisies van godsdienstige kultes. Tucker (1989:16) definieer 'n kultus as 'n godsdienstige groep wat 'n "profetiese" stigter het wat sogenaamd deur God geroep is om 'n spesiale boodskap deur te gee wat nie in die Bybel self gevind word nie. Om dit "op gesaghebbende wyse" te kan doen, is die leierskapstyl outoritêr; die organisasie word voorts as eksklusief gesien en die gesag daarvan word bevestig deur 'n wettiese lewenstyl en 'n vervolgingsmentaliteit. Martin (1980:16) definieer 'n kultus as 'n godsdienstige groep wat rondom 'n leier of groep leiers vergader is. Kultusse glo dat hulle die stem van God op aarde hoor en verwag dat hulle lede hulle om hierdie rede blindelings sal navolg. Bybelse leerstellings word verwerp en in die plek daarvan word hulle eie interpretasies geplaas wat volgens hulle in ooreenstemming met die Skrif is.

Daar is ooreenstemming tussen kenners van kultusse dat 'n kultus sekere algemene kenmerke vertoon. Samevattend kan 'n kultus gedefinieer word as 'n godsdienstige groep met 'n outoritêre leier of leierskap wat na bewering eksklusief 'n nuwe openbaring van God ontvang het. Die goddelike sanksionering wat die leier(s) geniet omdat hulle as gesante van God beskou word, word deur hulle gebruik om die lede se hele aardse sowel as ewige bestemming te beheer. Lede volg robotagtig die voorskrifte van die groep na omdat hulle dink dat hulle saligheid daarvan afhang en daar word aan hulle voorgehou dat hulle geen ander keuse het nie. Buite die groep, wat as die "ware volk" van God beskou word, is daar geen verlossing nie (Pretorius 1998:12). Dit is ook belangrik om te meld dat lede van baie kultes in isolasie leef as gevolg van die samestelling, gesagstruktuur en funksionering van dié kultusse (Pretorius 1998:96). 


\subsection{Kultus leiers, alias "profete"}

Soos blyk uit bogenoemde definisies van 'n kultus word die leiers van kultusse erken as "gesante van God" of "profete" wat die gawe ontvang het om "God se Woord" vir die tyd aan sy volk te bring. Die woord kultus het vir sommige " $n$ negatiewe konnotasie. Die meer aanvaarbare woord wat deesdae gebruik word waaronder kultus ingesluit word is, nuwe godsdienstige- of alternatiewe godsdienstige groepe.

David Berg, die leier van die groep bekend as Children of God, noem homself byvoorbeeld die Profeet van die Apokalips (Jordan 1996:114). Hennie van Niekerk van die Emmanuel Fellowship in die Limpopo-provinsie is oortuig dat hy 'n profeet van God is met 'n besondere gawe (Van Niekerk 2004).

Oigen Houy van die Houy-groep net buite Volksrust hou homself voor as 'n profeet (Erasmus 2004:14); 'n Gesant van God en 'n spreekbuis van Bo (Van Wyk 1995:5). Lester Bloomberg van The Mission Church in Brooklyn is deur sy volgelinge beskou as Ware Leermeester en die enigste Ware Profeet (Botha 1993:11). David Koresh van die Branch Davidians het hom aan sy volgelinge voorgestel as die Nuwe Messias (Jordan 1996:112-113). Sun Myung Moon van die Unification Church stel homself voor as die verpersoonliking van die tweede koms van die Messias (Jordan 1996:122).

Aansprake van hedendaagse profete, soos dié hierbo, bring die oortuiging by hulle volgelinge dat hulle as spreekbuis van God optree en met totale onderdanigheid gehoorsaam moet word. Dié "profete" word beskou as "gestuurdes van God". Hierdie oortuiging van 'n sogenaamde goddelike roeping word verder by die volgeling ingeboesem deur hulle te herinner dat die gesant van God gerespekteer en gehoorsaam moet word ten einde hulle nie God se toorn op die hals te haal nie. Die volgelinge van sulke hedendaagse profete volg daarom hulle opdragte blindelings na en hou onwrikbaar vas aan die hulle profesieë.

\subsection{Kenmerke van hedendaagse profete}

Hedendaagse profete verkry meestal geloofwaardigheid in die oë van hulle volgelinge omdat hulle aan sommige van die eienskappe van die Bybelse profete voldoen. Hulle maak aanspraak daarop dat hulle die roeping as profeet, en daarmee saam 'n openbaring, van 
God ontvang het. Die boodskap wat hulle van God ontvang het, is ook 'n spesifieke boodskap vir die tyd.

David Koresh, van die Branch Davidians het sy roeping in 1984 in Israel ontvang toe hy vir 'n kort tydjie weggevoer is na die hemel waar hy getransformeer is as die apokalitiese "ridder op die wit perd". Die boodskap wat hy ontvang het, is die finale boodskap van God: die sogenaamde sewende seël van die boek Openbaring. Hy is die sewende boodskapper (Jordan 1996:112-113). Op sestienjarige ouderdom het Sun Myung Moon van die Unification Church na bewering ' $n$ boodskap van Jesus Christus ontvang terwyl Hy in 'n visioen aan hom verskyn het. Volgens dié boodskap gaan God die wêreld deur hom (Moon) verander. Hy gaan die werk van Jesus wat Hy, as gevolg van sy voortydige dood, nie kon voltooi nie, voortsit en voltooi (Jordan 1996:122; Martin 1992:338). Oigen Houy van die Houy-groep beweer dat hy 'n openbaring van God ontvang het dat sy vrou en kinders en die man en kinders van 'n vrou genaamd Marie (met wie hy 'n buite-egtelike verhouding gehad het) gaan sterf. Dit is volgens hom 'n ingryping van God sodat hy en Marie kan trou en sendingwerk in Afrika kan gaan doen. Hy verklaar ook later dat hy geroep is om die "ware liggaam en bruid van Christus" op aarde te vestig (Erasmus 2004:14). Francis, die "profeet" van Hertzogville wat verkondig dat ' $n$ ene Paul Meintjies uit die dood sal opstaan, se volgelinge vertel ook van die besondere gawe wat Francis van God ontvang het. Hy het reeds deur hierdie gawe blindes laat sien en dowes laat hoor in die swart woonbuurt van Hertzogville, Malebogo (De Kock 2004:6).

Daarbenewens vertoon hedendaagse profete 'n aantal bykomende kenmerke. Hierdie kenmerke sluit onder andere in 'n charismatiese persoonlikheid. David Berg het sy besondere charisma en vermoë om te oortuig aangewend om duisende individue se lewens te verwoes (Jordan 1996:115). Houy is volgens Erasmus (2004:15) 'n goeie orator en sy tipe bediening het groot byval gevind by die mense. Jordan (1996:101) beskryf die persoonlikhede van die hedendaagse profete soos volg: "That the individuals who inspire religious cults possess some intrinsic factor in their personality that sets them apart from others is undeniable". Verder vertoon hulle normaalweg 'n vyandigheid teenoor die tradisionele kerk. Bloomberg, die "profeet" van The Mission Church, leer sy volgelinge dat alle Christelike leiers en kerke vals is, klaar veroordeel is en bestem is vir die hel (Botha 1993:7). Houy beskryf 
die tradisionele kerke as uitgedien en nutteloos. Ook die gesagstrukture in die kerke is volgens hom negatief. Hy en sy groep het die kerk nie nodig nie; hy verklaar trouens: "Die liggaam van Christus hou toesig oor homself sodat dit nie dwaal nie" (Houy 1995:81). David Francis, die profeet van Hertzogville, sê dat God die kerk beskou as 'n "wishy-washy convenient, compromising, candy coated Christian club collecting cover charge Christians". Die kerk wat hy beskryf as Churchianity gaan volgens hom nog die toorn en heerlikheid van God aanskou (Nel 2004:3).

Buite-bybelse bronne word ook deur hedendaagse profete ingespan om hulle leerstellings te bevorder. Moon het sy eie weergawe van die Bybel, bekend as Divine Principle, ontwikkel wat al sy leerstellings bevat. Moon se volgelinge verstaan en interpreteer die Bybel deur middel van die Divine Principle (Martin 1992:340). Een van Houy se bekendste geskrifte is Die Exodus van God se Volk uit die slawerny van Antichris (1995). Deur middel van hierdie geskrif, wat met dieselfde gesag as die Bybel hanteer word, verkondig hy sy leerstelling dat lidmate van verskillende kerke 'n uittog sal onderneem na sy groep.

Die belangrikste en waarskynlik die magtigste instrument in die hand van hierdie profete is die gawe om te profeteer of voorspellings te maak en, meer nog, die skynbare gesag wat hulle besit om goddelike profesie wat nie in vervulling tree nie, aan te pas.

\subsection{Aanpassing van profesieë}

Die skynbare "nie-vervulling" van die profesie word nie deur die volgelinge beskou as ' $n$ vals profesie nie. Die profeet is immers van God en God self kan nie 'n fout begaan nie. Erkenning dat die profeet 'n fout begaan het, sal sy/haar gesag as "gesant van God" aantas. Die rede waarom 'n profesie nie in vervulling tree nie, word dan aangegee as óf die sonde óf die ongeloof van die mens. Daar is altyd menslike deelname ter sprake by hierdie profesieë. As God en die profeet dus nie kan fouteer nie, moet dit die mense wees wat verhinder dat die profesie in vervulling tree. Die aanpassing van die profesie word ook deurgegee as komende van God. Op hierdie wyse poog die "profeet" om die goddelike element van die profesie behoue te laat bly.

Die Wagtoring organisasie, beter bekend as Jehovah se Getuies, se leiers wat beskou word as die "spreekbuis van Jehovah God", het voortdurend aan die profesie wat die slag van 
Armageddon aankondig, verander. Gedurende 1940-41 het die Wagtoring organisasie voorspel dat die slag van Armaggeddon binne enkele maande sou plaasvind. Lede is ook opdrag gegee om enige planne om in die huwelik te tree of kinders te hê uit te stel tot ná die slag van Armageddon. Hierdie profesie het nooit gerealiseer nie en is later uitgeskuif na 1975, met 'n ander opskrif, naamlik dat dit die jaar sal wees waarin die millennium sou aanbreek en die koninkryk van God op die aarde gevestig sou word. Die organisasie het besef dat ook hierdie voorspelling, wat nie in vervulling getree het 6000 jaar nadat Eva geskape is nie, aangepas moet word. Die organisasie het die regstelling gedoen deur aan te voer dat die voorspelling nie in vervulling getree het nie waarskynlik omdat Eva later as Adam geskape is en die volle 6000 jaar nog nie verloop het nie (Hunt 1980:207).

Oigen Houy het voorspel dat, rondom die verkiesing in 1994, die kerke gaan leegloop en kerkgeboue as graansilo's gebruik gaan word. Pretoria gaan platgevee word en die bloed gaan in Volksrust se strate loop. Volksrust se naam gaan verander na Moorddal. Oorlog soos nooit tevore nie gaan uitbreek en twee derdes van die bevolking gaan omkom. Die lede van die Houy-groep op Sion (die vesting van die groep) sal egter veilig wees (SAUK 1996: Koinonia-video). Van hierdie voorspellings van Houy het niks gekom nie. Houy verklaar dat die voorspellings wat hy gemaak het, op daardie tydstip geldig was maar later nie noodwendig meer geldig was nie. Andersins verklaar hy dat daar 'n vertraging in die profesie is en dat dit nog gaan plaasvind (Erasmus 2004:70).

Die leier van die Unification Church, Sun Myung Moon, het jare gelede voorspel dat hy die wêreld sal oorneem. Hierdie voorspelling het tot op hede nog nie waar geword nie. Herbert W Armstrong van die Worldwide Church of God voorspel dat sy kerk in 1972 weggeraap sou word na die antieke stad Petra naby die Dooie See en dat Christus in 1975 sou terugkeer na die aarde (Hunt 1980:201). Die beroemde profesie deur Joseph Smith van die Mormone in 1833 dat veelvuldige rampe die VSA sou tref en die goddelose van die land sou afvee, asook die belofte dat die Mormone 'n veilige hawe in Missouri beloof is (Hunt 1980:2-3), het ook nie gerealiseer nie. Plaaslik het die profesieë van Lester Bloomberg van The Mission Church ook nie in vervulling getree nie. Bloomberg voorspel deur middel van profesie dat (1) Welkom op 18 April 1988 in 'n sinkgat sal verdwyn; (2) die AWB in Mei 1988 'n 
staatsgreep gaan uitvoer; en (3) die Voortrekker-Monument op 16 Desember 1987 deur weerlig getref sal word en in twee sal verdeel (Theron 1993:287).

David Francis, die profeet van Hertzogville, het ook voorspel dat Meintjies, een van sy volgelinge, uit die dood sou opstaan. Hy het ná die dood van Meintjies sy naasbestaandes laat weet dat God se boodskap aan hom is dat hulle Meintjies nie moet begrawe nie omdat hy uit die dood sal opstaan (De Wet 2004:5). Hierdie profesie is alreeds 'n korreksie van 'n vorige persoonlike profesie aan Meintjies waarin hy aangekondig het dat Meintjies 85 jaar oud sou word (De Vries 2004). Meintjies het egter voortydig, volgens die voorspelling, op 76-jarige ouderdom gesterf. David Francis het hierdie voortydige dood, wat as't ware sy voorspelling as vals bewys het, reggestel deur sy laaste voorspelling dat God 'n groter wonderwerk gaan doen deur Meintjies uit die dood op te wek (De Vries 2004). Francis het wel een Sondagaand, na bewering 1 Augustus 2004, by die lykshuis opgedaag om Meintjies uit die dood op te wek. Met die Bybel in die hand en sy skoene uitgetrek het hy die deel van Lasarus se opwekking in die Bybel oor en oor herhaal. Toe daar egter niks gebeur nie, het Francis glo aan Foulds, die begrafnisondernemer wat ook teenwoordig was, gesê: "I have got the event right but not the time" (Foulds 2004). Francis korrigeer die voorspelling en verduidelik dat die opstanding wel nog sal plaasvind en dat alles nie verlore is nie. Alhoewel Francis beweer dat hy nie 'n spesifieke datum verstrek het waarop Meintjies sou opstaan nie, het hy tog deur sy optrede en opdragte 'n tydraamwerk waarbinne dit moes gebeur, gegee. Die feit dat Meintjies nie begrawe moes word nie, het die verwagting gelaat dat dit binnekort sou wees. Verder het hy met sy besoek aan die lykshuis en die poging om Meintjies op te wek aangedui dat die opstanding toe reeds moes plaasgevind het. Tot op hede het nog niks gebeur nie. Paul Meintjies het tot op datum nie uit die dood opgestaan nie. Meintjies gaan egter nog steeds uit die dood uit opstaan, aldus sy seun (Meintjies 2004).

\subsection{Hedendaagse profete getoets}

Daar is reeds aangetoon dat een baie belangrike eienskap van 'n ware profeet die vervulling van sy/haar profesie is. In die wêreld van die hedendaagse profeet blyk die vervulling van 'n profesie nie so belangrik te wees nie, te oordeel aan die voordurende aanpassing van die profesie. 
In die lig van die voorgaande is dit duidelik dat die profesieë wat deur hedendaagse profete soos Francis voortgebring word, nie die toets van die profeet slaag nie. Dit ontbreek dié profesieë nie net aan die goddelike element omdat dit nie in vervulling tree nie, maar skep ook met die voordurende aanpassing daarvan die idee dat God nie sy woord hou nie.

\subsection{Evaluering van hedendaagse profete}

Hedendaagse profete wat daarop aanspraak maak dat hulle deur God geroep en gestuur is, moet voldoen aan die kriteria wat voorheen gestel is. Seker die belangrikste kriterium is dat die profesie of voorspelling van die "profeet" in vervulling moet tree volgens Deuteronomium 18:20-21. Indien 'n profeet se profesie nie in vervulling tree nie, word hy/sy beskou as 'n vals profeet.

Dit is uit bogenoemde duidelik dat die hedendaagse profete, en veral die profeet van Hertzogville, wat hulleself beskou as profete van die aard van die Ou-Testamentiese profeet, nie aan hierdie enkele toets vir 'n ware profeet voldoen nie. Die vae en ontwykende wyse waarop Francis reageer, dui nie op een van die belangrikste eienskappe, naamlik geloofwaardigheid, nie. 'n Ware profeet bring die boodskap van God met oortuiging. Derhalwe kan hedendaagse profete soos Francis in die lig van die Bybel nie as ware profete beskou word nie. Die profete van ouds het in 'n bepaalde tydvak in die geskiedenis van God se bemoeienis met sy volk gefunksioneer. Hedendaagse profete kan nie aanspraak maak daarop dat hulle in dieselfde sin as die profete van die Bybel profete is nie.

\section{GEVARE VAN HEDENDAAGSE PROFETE EN PROFESIE}

Die regte van individue geniet baie aandag in die tyd waarin ons leef. Die mishandeling van kinders en vroue is sake wat baie aandag geniet. Selfs wreedheid teenoor diere word as belangrik beskou. Een aspek van mishandeling wat egter skandelik afgeskeep word, is geestelike mishandeling in die godsdienstige konteks, wat in baie gevalle die gevolg van geestelike misleiding is.

Geestelike misleiding in hierdie verband vind hoofsaaklik plaas wanneer 'n sogenaamde "woord van God" of "profesie" misbruik word om die motiewe van die een wat dit misbruik, te dien. Soos reeds aangetoon, word goedgelowige mense deur die misbruik van 'n sogenaamde "woord van God" in so 'n mate beïnvloed dat 
hulle as 't ware robotagtig optree volgens die opdragte van hierdie "profete". Die bewering dat hulle deur God gestuur is met 'n nuwe opdrag wat vervat is in die sogenaamde openbaring, vorm die grondslag van die gesag wat "profete" oor hulle volgelinge uitoefen. Hierdie goddelike sanksionering gee soveel mag aan hierdie leiers dat hulle uiteindelik die totale lewe van hulle volgelinge beheer. Dit kom indirek daarop neer dat die leier "God" speel in sy volgelinge se lewens.

Hierdie optrede deur sogenaamde profete lei daartoe dat die regte van individue soos vervat in die Grondwet van die Republiek van Suid-Afrika 1996 (Hoofstuk 2 ) misken word.

Die volgende aspekte van die regte van die volgelinge van sommige van hierdie hedendaagse profete laat vrae ontstaan.

Die Grondwet van die Republiek van Suid-Afrika 108 van 1996 bepaal soos volg in artikel 31(1):

(1) Persone wat aan 'n kultuur-, godsdiens- of taalgemeenskap behoort, mag nie die reg ontsê word om, saam met ander lede van daardie gemeenskap -

(a) hul kultuur te geniet, hul godsdiens te beoefen en hul taal te gebruik nie; ...

In kultusse word lede, alhoewel betoog word dat hulle uit vrye wil by die groep aangesluit het, hierdie reg subtiel ontneem. 'n Sogenaamde profetes van 'n groep bekend as The Way, het uitdruklik aan haar volgelinge gesê dat hulle slegs Engels mag praat omdat dit die taal van die hemel is (Pienaar 2004). Die volgelinge wat Afrikaanssprekend is, is dus die reg ontneem om hulle eie taal te gebruik. Die profetes slaag daarin om hierdie reg te ontneem onder die dekmantel van godsdiensvryheid en die skynbaar goddelike sanksionering wat sy geniet.

Dit is ' $n$ algemene kenmerk dat volgelinge van hierdie profete ook baie dikwels bande met familie en vriende verbreek. Die rede hiervoor is dat hulle toewyding aan "God" en die profeet dit vereis. Die volgelinge se reg op vryheid van assosiasie word hier in gedrang gebring (art 18). Watters (1986:1), 'n kenner op die gebied van kulte, wys daarop dat kultuslede hierdie reg ontneem word deur die verbod daarop om met enigiemand buite die groep te assosieer omdat so 'n assosiasie daartoe sal lei dat volgelinge van die "waarheid" af weggetrek word. Volgelinge word ook verbied om materiaal van 
ander godsdienstige groepe te bestudeer, veral dan ook enige kritiese materiaal of stukke van oudlede. Pienaar (2004) bevestig dat in die plaaslike groep bekend as The Way, waarby hy betrokke was, hulle belet is om enige materiaal te lees as dit nie eers deur die profetes goedgekeur is nie.

Elke mens het volgens die Grondwet die reg dat sy/haar waardigheid gerespekteer word (art 10). Hierdie reg van baie van die volgelinge van hedendaagse profete word hulle ontneem. Hennie van Niekerk van 'n plaaslike groep bekend as die Emmanuel Fellowship, lê sy volgelinge fisiese straf op. Een van sy vroulike volgelinge moes in 'n land wat hy omgeploeg het, aartappels met die hand plant. Toe die aartappels begin vrug dra, het hy weer die land omgeploeg met die woorde "moenie dink dat jy of enige iemand van die vrug van jou hande sal eet nie" (Van Niekerk 2004). Die vroulike volgeling moes hierdie straf uitdien omdat sy volgens Van Niekerk ongehoorsaam was aan God. Die vraag in hierdie geval is nie of die volgeling se waardigheid misken is nie, maar in watter mate dit ontken is.

Uit die enkele voorbeelde hierbo genoem, is dit duidelik dat daar 'n groot leemte bestaan wat betref die regte van individue wat betrokke raak by sommige hedendaagse profete en hulle groepe.

\section{GEVOLGTREKKING}

Dit blyk duidelik uit bogenoemde dat daar persone is wat rondgaan en hulleself voorhou as profete van God, terwyl hulle nie die karaktertrekke van 'n ware profeet vertoon nie. Ongelukkig word talle onskuldige, goedgelowige mense deur hierdie aansprake mislei. Dit het tot gevolg dat hulle hul totale lewe wy aan die profeet en sy/haar sogenaamde bediening. Die meeste van hierdie groepe leef in isolasie, wat tot gevolg het dat die groepslede totaal vervreem word van die wêreld buite die groep. Bande met familie en vriende word verbreek en die profeet en sy/haar organisasie vervang selfs die onafhanklike denke, oordeelsvermoë en ambisie van die volgeling met " $n$ totale afhanklikheid van die "profeet" en groep. Op dié wyse word die volgeling so afhanklik gemaak van die profeet en die groep dat hulle moeilik hulle bande met die groep breek en die wêreld buite die groep as hulle vyand ervaar.

Gevolglik kan hierdie misleide volgelinge nie bereik word deur iemand buite die groep nie. In die toestand van isolasie geniet die hedendaagse profeet vryheid om die volgelinge te misbruik, terwyl 
hulle oortuig is dat hulle God se woord en wil gehoorsaam. Die ontkenning van die regte van hierdie volgelinge word oor die hoof gesien, nie net deur die profeet nie, maar ook deur die breë gemeenskap. Daar word aanvaar dat 'n individu die reg het om tot die godsdienstige groep van sy/haar keuse te behoort. Die vraag is egter of die reg op godsdiensvryheid uitgebuit mag word om die individu van ander regte te ontneem. Mag die "profeet" deur sy/haar profesie en die funksionering van sy/haar groep sy/haar volgelinge ontneem van hulle reg op vryheid van assosiasie (art 18); hulle reg op vryheid van uitdrukking (art 16) en hulle reg op vryheid van beweging en verblyf (art 21), om maar enkeles te noem, omdat die volgelinge uit vrye keuse daar is? Wat dikwels in die beredenering van hierdie kwessie buite rekening gelaat word, is dat die "profete", in groot mate deur subtiele manipulasie van die sogenaamde "woord van God", volgelinge beweeg om radikaal op te tree. Wie tree in die bresse vir die regte van die individue wat deur hierdie hedendaagse profete misbruik en wie se regte hulle ontneem word? 'n Organisaie bekend as Verleen Regte aan Individue (VERI) het onlangs tot stand gekom om aan hierdie leemte aandag te gee.

\section{Literatuurverwysings}

Aune, D E 1983. Prophecy in Early Christianity and the Ancient Mediterranean World. Grand Rapids: William B Eerdmans Publishing Company.

Botha, P R 1993. Mind Control and the Bloomberg Cult. Pretoria: Ongepubliseer (Oud-kultlid van Bloomberg se Mission Church)

Bright, J 1959. History of Israel. Philadelphia: Westminister Press.

De Kock, G 2004. Vandag is die dag, tog roer oom Paul nie. Rapport, 1 Aug, 6.

De Vries, A 2004. Persoonlike mededeling te Hertzogville. 25 Augustus 2004.

De Wet, T 2004. Profeet erg onsteld oor datum vir opstanding. Beeld 22 Julie, 5 .

Erasmus, J J J 2004. Die Houy Groep: Kerk of Kulte? Potchefstroom: MThskripsie.

Forbes, C 1995. Prophecy and inspired speech in early Christianity and its hellenistic environment. Tübingen: JCB Mohr.

Foulds, N 2004. Persoonlike medeling deur begrafnisondernemer te Hertzogville. 25 Augustus 2004.

Freeman, H E 1971. An Introduction to the Old Testament Prophets. Chicago: Moody Press.

Grondwet van die Republiek van Suid Afrika, 1996. Kaapstad: Juta. 
Houy, E 1995. Die Exodus van God se volk uit die slawerny van Antichris. Algemene omsendbrief. Oktober 11.

Heschel, A J 1971. The Prophets Part II. New York: Harper \& Row Publishers.

Hunt, D 1980. The cult explosion. California: Harvest House.

Jordan, M 1996. Cults, Practices \& Personalities. Britian: British Library.

Jurgensen, B 1977. The Prophets speak again. Minneapolis: Augsburg Publishing House.

Martin W R (ed) 1980. The New Cults. Ventura: Regal Books.

Martin, W R 1992. The Kingdom of Cults. Minneapolis: Bethany House.

Matthews, V H 2001. Social World of the Hebrew Prophets. Massachusetts: Hedrickson Publishers.

McKenna, M 2001. Prophets Words of Fire. New York: Orbis Books.

Meintjies, P 2004. Persoonlike medeling deur Pieter Meintjies, seun van die afgestorwe Paul Meintjies. 26 Augustus 2004.

Napier, B D 1962. 'Prophet, Prophetism', in: Buttrick, G A, Interpreter's Dictionary of the Bible. Nashville: Abingdon.

Nel, J 2004. 'Profeet' kryt kerk uit, maar swyg oor oom Paul se opstaan. Beeld, 13 Aug, 4.

Pienaar, E 2004. Persoonlike mededeling. 3 September 2004.

Pretorius, S P 1998. Evangelieverkondiging aan kultelede met spesifieke verwysing na Jehovah-Getuies. Potchefstroom: PU vir CHO. (Proefskrif $\mathrm{PhD})$.

Sandmel, S 1963. The Hebrew Scriptures. New York: Knopf.

SAUK, 1996. Godsdienstige Kultusse, Koinonia-video.

Schultz, S J 1968. The Prophets Speak. New York: Harper \& Row Publishers.

Theron, J P J 1993. When a 'Word of Prophecy' becomes the 'Word of God', Missionalia vol. 21(3), 287-310.

Tucker R A 1989. Another gospel: Alternative Religions and the New Age Movement. Grand Rapids: Zondervan.

Van Niekerk, A 2004. Mededeling aan Special Assignment, SABC3, 11 Mei.

Van Wyk, P 1995. Die 'Profeet' word in eie dorp gevrees. Rapport, 5 Maart.

Watters, R 1986. Do Cults Follow the Same Pattern? Bethel Ministries Nov/Dec. Newsletter 5(6), 1-3.

Winward, S 1969. A Guide to the Prophets. Richmond: Knox.

Zucker, D J 1994. Israel's Prophets. New Jersey: Paulist Press. 